\title{
Recent Advances in Onion Genetic Improvement
}

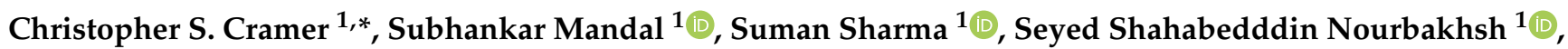 \\ Irwin Goldman ${ }^{2}$ and Ivette Guzman ${ }^{1}$ \\ 1 Department of Plant and Environmental Sciences, New Mexico State University, Box 30003, MSC 3Q, \\ Las Cruces, NM 88003, USA; mandals@nmsu.edu (S.M.); suman30@nmsu.edu (S.S.); \\ nshahab@nmsu.edu (S.S.N.); ivguzman@nmsu.edu (I.G.) \\ 2 Department of Horticulture, University of Wisconsin-Madison, 1575 Linden Dr., Madison, WI 53706, USA; \\ ilgoldma@wisc.edu \\ * Correspondence: cscramer@nmsu.edu
}

Citation: Cramer, C.S.; Mandal, S.;

Sharma, S.; Nourbakhsh, S.S.;

Goldman, I.; Guzman, I. Recent Advances in Onion Genetic Improvement. Agronomy 2021, 11, 482. https://doi.org/10.3390/ agronomy 11030482

Academic Editor: Alan Walters

Received: 29 December 2020

Accepted: 4 March 2021

Published: 5 March 2021

Publisher's Note: MDPI stays neutral with regard to jurisdictional claims in published maps and institutional affiliations.

Copyright: (C) 2021 by the authors. Licensee MDPI, Basel, Switzerland. This article is an open access article distributed under the terms and conditions of the Creative Commons Attribution (CC BY) license (https:// creativecommons.org/licenses/by/ $4.0 /)$.

\begin{abstract}
Onions are one of the most important vegetable crops worldwide. However, their production faces many challenges. Genetic improvement is one mechanism to address those challenges. In this review, we discuss recent research pertaining to the diseases Fusarium basal rot and Iris yellow spot, the insect pest onion thrips, onion pungency, and dormancy. Recent research for screening onion bulbs for Fusarium basal rot resistance has resulted in improved screening techniques and germplasm exhibiting less disease when inoculated with the disease-causing pathogen. Improved screening methods have resulted in germplasm exhibiting fewer and less severe Iris yellow spot symptoms when onion thrips and conducive environmental conditions are present. Onion germplasm with less and differing compositions of epicuticular wax on their leaves have shown a nonpreference for thrips feeding and have the potential for developing thrips tolerant cultivars. Conventional breeding efforts and genetic manipulation of the genes producing alliinase and lachrymatory factor synthase has resulted in low pungency, tearless onions. In long-day onions, an annual generation time has been achieved by artificially breaking bulb dormancy early while ensuring proper vernalization has been completed. Genetic improvement of these and many other onion traits will continue and result in better production in the future.
\end{abstract}

Keywords: Fusarium basal rot; Fusarium oxysporum f. sp. cepae; Iris yellow spot; Iris yellow spot virus; onion dormancy; onion pungency; onion thrips

\section{Introduction}

Onion (Allium cepa L.) is one of the most important vegetable crops worldwide. Of the total vegetable production worldwide, onion accounts for around $24 \%$ of the total [1]. They are an integral part of many cultures and cuisine; are grown in many countries worldwide; and are adapted to many different growing environments. The bulbing daylength sensitivity that influences bulbing initiation allows for onion production in various latitudes and altitudes in the northern and southern hemispheres [2]. Onion cold tolerance enables it to be grown during the winter months in lower latitudes and altitudes and the summer months in higher latitudes and altitudes [2]. As with many crops, onion breeding research faces many challenges. Since onions are a biennial plant species that results in a generation time of two years, seed production for research requires more time and effort than annual crops. In the first year after seed sowing, plants produce a bulb from the basal portions of leaves in response to lengthening daylengths [2]. Once a bulb has been fully formed, it will enter a period of dormancy. For flowering to occur in the second year, plants or bulbs must undergo a vernalization period in which the vegetative apical meristem is transformed into a reproductive meristem [2]. Flowering can be initiated in the first year; however, bulb selections cannot be made [2]. Research has been done in the long-day onion to shorten the generation time to one year [3]. To achieve a generation time of one year, 
onion dormancy must be broken early while ensuring proper vernalization occurs [3]. In addition, to accelerate the process in temperate environments, onion flowering and seed production must occur in a controlled environment to ensure that seed is ready in time for planting the next generation [3]. Onions are a cross-pollinating plant species that require isolation by distance or a barrier to prevent genetic contamination [2]. An insect pollinator is employed for proper pollination. For controlled crosses, hand emasculation is quite tedious; however, a cytoplasmic genic male sterility system exists that allows for efficient hybrid seed production [2,4]. Onions decline in vigor when self-pollinated and will suffer inbreeding depression visualized through smaller bulbs, fewer flowering scapes, smaller umbels, and lower seed production after several cycles of self-pollination [2,4].

As with many crops, onions face many insects, fungal, bacterial, viral, and nematode pests. The main insect pests are onion thrips (Thrips tabaci Lind.), onion maggot (Delia antiqua Meigen), and Allium leafminer (Phytomyza gymnostoma Loew). Onions face a myriad of fungal diseases, including pink root, Fusarium basal rot, Stemphyllium leaf blight, purple blotch, Botrytis leaf blight, black mold and white rot [5]. Some of the bacterial diseases of onion include bulb soft rots, Xanthamonas leaf blight, center rot, slippery skin, and sour skin [5]. The main viral disease is Iris yellow spot caused by the Iris yellow spot virus (IYSV) [6].

Research has also focused on traits related to bulb yield and quality. In onion, bulb yield is a function of bulb size and plant density. Bulb size is often a function of plant size. As onion bulbs are destined for either fresh market or processing, many bulb quality traits are studied. For the fresh market, onion pungency, dry outer scale, and storability traits are essential. For processing, the percentage of single centered bulbs and the percentage of soluble solids are important quality traits. This review will focus on recent research to improve resistance to Fusarium basal rot (FBR), to improve resistance to Iris yellow spot (IYS) disease, to improve tolerance to onion thrips, and to further understand onion pungency and dormancy.

\section{Fusarium Basal Rot}

Fusarium basal rot (FBR) is a highly destructive soil-borne fungal disease of onion caused by Fusarium oxysporum Schlechtend.: Fr. f. sp. cepae (H. N. Hans.) W. C. Snyder \& H. N. Hans. (FOC) [7]. Symptoms of FBR include delayed emergence and damping-off of young seedlings; leaf chlorosis and necrosis of mature plants; and brown discoloration in the basal stem plate of mature bulbs that can lead to root death, root abscission, and plant death [7]. In its most severe form, this disease produces external white mycelial growth in the adjacent scales and allows for secondary infection to occur [7]. Since it was first documented in the onion fields of Ohio in 1910 [8], virulent FOC isolates have been identified worldwide, viz., Australia, Germany, Iran, Ireland, Israel, Netherlands, New Zealand, Spain, Turkey, United Kingdom, United States, and Uruguay [9-15]. Management practices against FBR include crop rotation, solarization, fungicides, biological control, and host plant resistance [7]. Among them, FBR resistant cultivars are the most promising means to control this disease which in turn will reduce the amount of land required for crop rotation [16], protect plants from inoculum build-up associated with monocropping [17]; and circumvent cost-prohibitive chemical treatments, such as soil fumigation [18].

Studies devoted to discovering the genetics of FBR resistance in onion found inheritance of single dominant genes, partially dominant genes, non-nuclear genes, and multiple genes [7]. Compared to the highly FBR resistant Welsh onion or Japanese bunching onion (Allium fistulosum L.), in which quantitative trait loci (QTLs) for FBR resistance were located in chromosome 8 [14], cultivated onion possesses FBR resistance QTLs on chromosomes 1, 6B, and 8 [19]. Even though QTLs for FBR resistance are being identified, the mechanism(s) of resistance against FOC is still a mystery. Onion breeders are always searching for different sources of FBR resistance to integrate them into commercial cultivars $[12,20,21]$. This search is complicated by the variability of FOC isolate virulence in different geographical 
regions [20], isolate-cultivar interactions [9], and daylength sensitivity of onion for bulb production [19].

In recent years, attempts have been made to ascertain virulence variation among different isolates of Fusarium species and isolate-cultivar interactions using morphological and/or molecular characterization. Other species besides F. oxysporum f.sp. cepae, have been reported to be involved in the onion basal rot disease complex. The characterization of $31 \mathrm{~F}$. oxysporum isolates was conducted using a pathogenicity test, gene sequencing and effector identification in which 21 were found to be pathogenic and ten putative effectors were recognized along with genes specific to FOC [22]. RNA-Sequencing to locate effector candidates in fungal organisms can be useful in effector-informed resistance breeding approaches [23]. Pangenomic comparisons were carried out to find the functional specificity of FOC chromosomes in which single molecule sequencing was used to reveal the parts of lineage-specific (LS) chromosome as pathogen-specific and non-specific in FOC [23]. In Egypt, 14 different isolates of Fusarium were collected from four states and all the isolates of three different species: F. oxysporum, F. solani (Mart.) Sacc., F. proliferatum (Matsushima) Nirenberg, were found to be pathogenic. F. oxysporum was the most virulent among the species and all of the isolates differed in their disease severity on onion bulbs and were categorized into separate groups [24]. A polymerase chain reaction (PCR) analysis was planned using inter simple sequence repeats (ISSR), random amplified polymorphic DNA and a pathogenicity test on 26 FOC isolates from major onion growing regions of Iran. ISSR based results and the pathogenicity test confirmed the genetic as well as virulencebased differentiation among isolates but with no correspondence to their geographic regions [13]. A draft genome sequencing was performed to find the similarity of an effector in F. oxysporum secreted in xylem 2 (SIX2) with F. proliferatum which was found to be a component of the FBR disease complex [25]. Similarly, 152 Fusarium isolates were studied for their virulence and at a molecular level using internal transcribed spacer primers in Turkey. Highly virulent strains of FOC varied in their virulence but exhibited only $1 \%$ differentiation among all the isolates presenting the same clonal lineage [26]. Recently in Finland, a specific molecular technique based on Whatman FTA ${ }^{\mathrm{TM}}$ filter paper Matrix along with a dual PCR test using F. oxysporum species specific and virulence specific primers was developed to identify latent infections in onion bulbs after harvesting. This method could be beneficial in screening of bulbs with low levels of latent infection [27]. Currently, four different species of Fusarium, F. proliferatum, F. oxysporum f.sp. cepae, F. acutatum Nirenberg \& $\mathrm{O}^{\prime}$ Donnell and F. anthophilum (A. Braun) Wollenw. were identified in northeastern Israel with colony, microscopic morphological characterization, and sequencing using Fusarium specific primers that grouped the isolates into two clades. All the isolates were pathogenic with varying degree of virulence and different onion cultivars exhibited variations in isolate sensitivity response in an onion bulb assay [15].

The two most popular screening methods used to evaluate cultivar reactions to FOC are a seedling screening with virulent FOC isolates in a controlled atmosphere and a field screening [12,28-30]. Both of these methods have been used routinely for identifying commercially available cultivars with a moderate to a high level of FBR resistance, e.g., 'Ailsa Craig Prizewinner' and 'White Lisbon' from the United Kingdom; and 'Isfahan', 'Kashan', 'Ghom', and 'Azarshahr' from Iran [12,29]. In Argentina, a comparison of selections from an onion breeding line made under natural field and artificial inoculation in controlled conditions was done and incidence of disease was greatly reduced in progeny generated under controlled conditions at high FOC concentrations [31]. A recurrent selection was followed in the field after making a selection of strong seedlings in the laboratory for achieving progress in FBR resistance [31]. Considering that there are no FBR resistant short-day onion cultivars available to date, the New Mexico State University (NMSU) onion breeding program sought to improve the FBR resistance of short-day commercial onion cultivars [28]. A comparison between the seedling and field screening methods to improve FBR resistance of seven short-day onion cultivars, NuMex Camino, NuMex Sweetpak, NuMex Chaco, NuMex Mesa, NuMex Crispy, NuMex Vado, and NuMex Luna, revealed that selection 
during the seedling stage did not improve the mature bulb FBR resistance that suggested a growth stage dependent resistance [28]. The field screening method was incapable of improving FBR resistance in both plant growth stages [28]. Individual plant selections based solely on a field screening could be challenging due to the nonuniform distribution of FOC isolates [32], suppressive soil formation with microbial antagonism [33], and a lack of propagule pressure [34] in the field. These obstacles are apparent in the absence of improvement in FBR resistance of short-day Argentinian germplasm, where selection has been accomplished primarily via field screening using recurrent selection strategies [31]. In some instances, FBR may be visualized only in mature bulbs during storage [7].

Two mature bulb inoculation methods were developed by the NMSU onion breeding program to select for FBR resistant bulbs [29]. As part of the process, transversely cut basal stem plates $(\sim 0.25-0.30 \mathrm{~mm}$ from the top) were inoculated artificially with potato dextrose agar plugs containing mycelia or conidia of a virulent FOC isolate, 'CSC-515' [21]. The absence of mature bulb FBR resistance for the selected populations using a mycelial inoculation suggested the possibility of disease escape by susceptible bulbs due to variable inoculum density and differential disease development [21]. In contrast, a conidial inoculation created a high and uniform amount of disease pressure irrespective of the cultivar's genetics and resulted in an effective selection of resistant bulbs (Figure 1) [21]. Disease pressure in the later method could be manipulated by changing the conidial concentrations of FOC isolate(s) depending on fungal virulence [21].

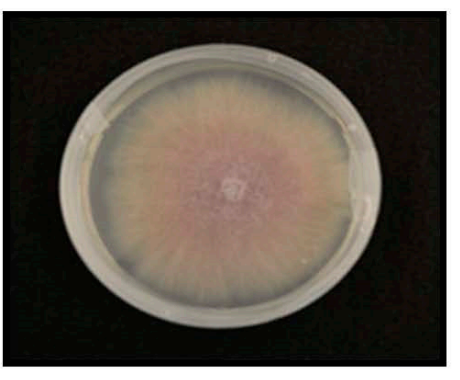

(a)

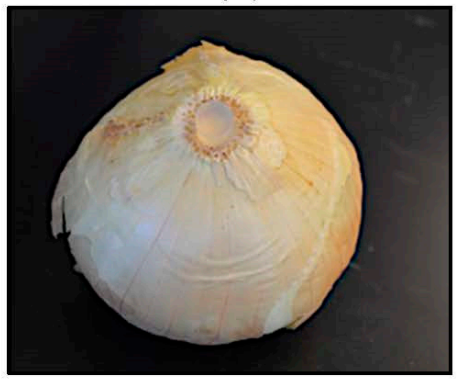

(c)

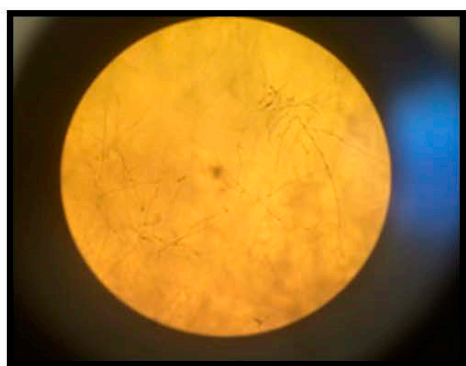

(b)

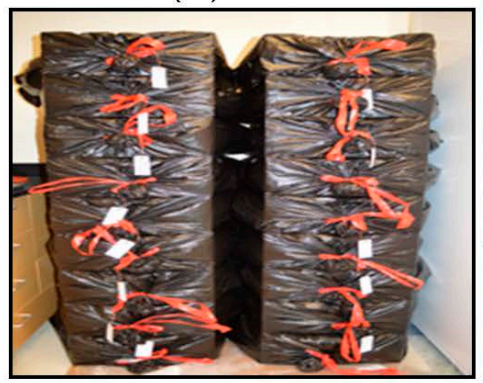

(d)

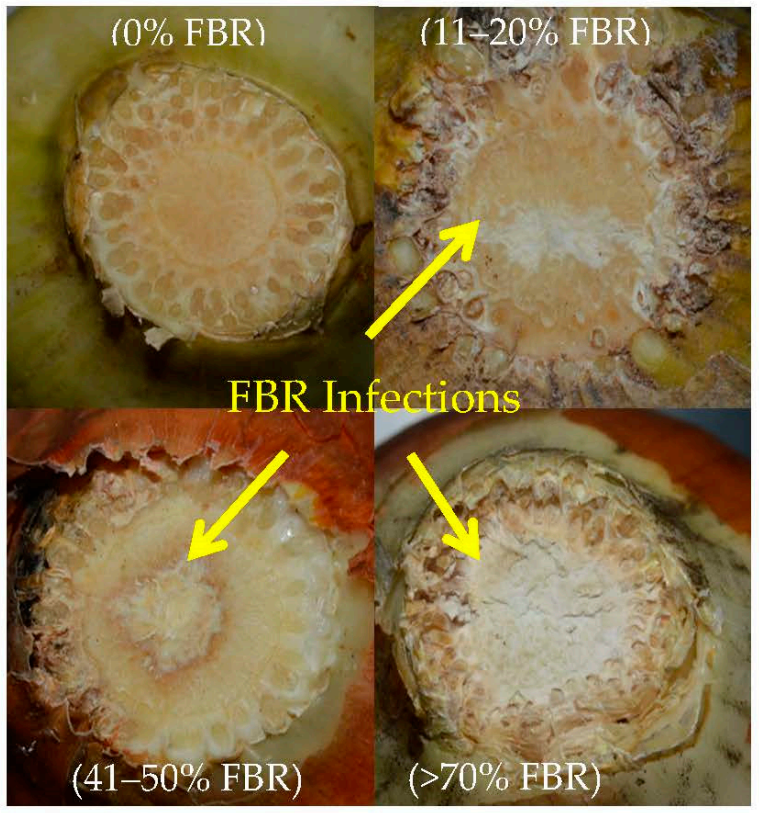

(e)

Figure 1. Conidial inoculation method developed by Mandal and Cramer (2020a) [21] to select FBR-resistant mature onion bulbs: (a) a culture of Fusarium oxysporum f.sp. cepae (FOC), (b) special potato dextrose agar (SPDA) media with suspended FOC conidia, (c) inoculation of a transversely cut basal plate with a SPDA plug, (d) initial ( 24 h) incubation of the inoculated bulbs under high humidity condition, and (e) visual scorings of FBR severity after 20 days of incubation. Adapted from Mandal and Cramer (2020a) [21]. Photos courtesy of SM.

The conidial inoculation has been used to evaluate FBR susceptibility reactions of NMSU short-day onion cultivars and select populations with reduced FBR severity and incidence $[21,35,36]$. Upon employing two cycles of phenotypic recurrent selection using the conidial inoculation technique, a significant reduction in FBR severity and incidence was achieved in selected populations compared to the original populations of the NMSU cultivars indicated above [36]. The inheritance of the resistance was additive as greater improvement was realized among the most advanced selected populations [36]. Other 
important attributes of the selected cultivar populations included slowing down the infection rate in the resistant bulb basal plate and reduced yearly variation of FBR severity and incidence [37]. These results suggest that FBR resistance is partial or quantitative resistance and governed by multiple factors, as established in other studies [14,19].

An increase in FBR resistance using phenotypic recurrent selection could be aided by improving the visual disease scoring method [12,21]. This method can result in disease escapes and may jeopardize any progress due to the highly outcrossing nature of this crop $[21,38]$. More objective identification of FBR symptoms has been developed by the NMSU onion breeding program using blue-green autofluorescence emitted by the FOC infected tissue [36]. High regression coefficient values for FBR severity $\left(R^{2}=0.9955\right.$, $p<0.001)$ and incidence $\left(\mathrm{R}^{2}=0.9863, p<0.001\right)$ scorings between the performed visual estimation and the image analysis indicated that the later could be used for high throughput phenotyping to select FBR resistant onion bulbs [36]. A preliminary biochemical analysis from this study involving two cultivars with a varying degree of susceptibility to FOC revealed that the partially resistant cultivar had a higher saponin content, a secondary metabolite in Alliums with antifungal activity [36,39]. Even though it warrants further investigation to establish a possible correlation between the degree of FBR resistance, saponin type, and its content in cultivars, biochemical selection may be able to identify onion plants with a higher amount of secondary antifungal metabolites, like steroidal saponins and phenols [39,40]. Allium accessions with FBR resistance, such as A. fistulosum, have been identified recently as part of a globally relevant cultivated onion germplasm set. These accessions could be exploited as a source for pyramiding resistance genes into commercial cultivars [19]. Five single nucleotide polymorphic markers developed in this study correlated well with FBR resistance and could be used for marker-assisted selection and may result in accelerated progress [19]. A. fistulosum monosomic addition lines (MALs) with an extra shallot (A. cepa Aggregatum group) chromosome 2A have served as potential germplasm sources for physiological studies [41]. The identification of a saponin compound in A. fistulosum and its antifungal properties along with RNA-Sequencing to discover the saponin biosynthesis pathway were found in this study. Advanced technologies such as RNA-Seq which uses the Next Generation Sequencing (NGS) technique for transcriptomic studies can be employed for gene discovery [41].

\section{Iris Yellow Spot and Onion Thrips}

Iris yellow spot (IYS), caused by the Iris yellow spot virus (IYSV) (family Bunyaviridae, genus Tospovirus), presents itself as small necrotic, irregular or diamond-shaped, strawcolored lesions that appear on leaves and flowering scapes [6]. These lesions can grow in size and coalesce into larger lesions that can encompass an entire leaf or girdle a scape that results in lodging. IYSV is vectored mainly by onion thrips (T. tabaci), that is the most important insect pest of onion in the US that infests and damages crops routinely and is a cosmopolitan, polyphagous insect [42]. Through thrips routine feeding, contents of mesophyll cells in onion leaves are removed, causing severe leaf damage and curling, and creating silvery patches on the leaves. These changes result in a 30-50\% reduction in bulb yields. Seed yield is also affected by thrips feeding due to lodging and girdling of flower scapes [43-45]. Juvenile thrips acquire IYSV by feeding on infected tissue and transmit IYSV to healthy plants through adulthood. Moreover, IYSV causes adult viruliferous thrips to have longer life spans and fecundity compared to nonviruliferous thrips, allowing them to infect more plants and worsening IYSV epidemics [46]. IYS also reduces yield through disease symptom expression and reduces photosynthetic area in both leaves and flower scapes $[47,48]$. Recent research suggests that IYSV causes onion plant gene regulation effects upon infection [49]. The virus causes up regulation of genes associated with retrotransposon proteins, disease resistance-like proteins, chitinase, a pathogenesisrelated protein, cytochrome oxidase, cytochrome $\mathrm{c}$, a pentatricopeptide repeat-containing protein and pectin methylesterase. In a similar study, IYSV was found to interfere with a chloroplast related gene in onion [50]. IYSV caused chloroplasts to be misshapen and 
ruptured in some instances while serving as a location for virus replication [50]. The gene sequence of the chloroplast related gene affected by IYSV showed a $99 \%$ similarity to a gene sequence associated with the normal $(\mathrm{N})$ cytoplasm genotype of the cytoplasmic-genic male sterility system in onion [50]. This result suggests that IYSV may have the ability to interfere with male fertility in onion.

Hot and dry $\left(>30^{\circ} \mathrm{C}\right)$ climatic conditions can shorten thrips generation times, increase thrips buildup, increase plant damage caused by thrips, and increase IYS symptom development and severity [51]. Currently, the primary management method of onion thrips is frequent applications of organophosphates, carbamates, and pyrethroids. This method of management is not sufficient since onion thrips have developed resistance to these commonly used chemicals. Additionally, thrips eggs are protected by leaf tissue; and prepupae, pupae, larvae, and some adults are in the soil or the inner spaces between leaves, making complete spray coverage very difficult to accomplish [43,52-54]. Limited effectiveness of insecticides for thrips control under these conditions, and increased insecticidal resistance of thrips leads to few effective means to control thrips and in turn IYS $[6,44,51,55]$. Complete host plant tolerance or resistance to thrips would be beneficial; however, no onion germplasm has been found to exhibit this trait $[6,51,56-58]$.

In the past few years, there have been efforts to create an integrated approach, including thrips control, cultural practices, and genetic resistance/tolerance, to control thrips damage. Host plant resistance and tolerance to thrips feeding offer an economical and environmentally friendly solution for thrips and IYSV control and reduce damage to onion crops $[51,56]$. Many onion breeding programs, including the NMSU onion breeding program, have evaluated and screened germplasm for reduced thrips numbers and IYS disease symptom expression over the last decade. In a 2019 study, many second-generation selections, including NMSU 12-257, 12-258, 12-260, 12-261, 12-774, 12-279, 12-289, and 12-325, exhibited a lower number of thrips when compared to a susceptible check cultivar, Rumba, and NMSU 12-279, 12-255, 12-298, 12-289 and 12-258, exhibited significantly fewer thrips when compared to their first-generation entries, indicating selection progress [56]. In a recently published study, progress in reducing IYS symptom expression, delayed symptom expression and reduced thrips population were observed in several breeding lines including NMSU 12-236, 12-243, 12-335, 12-337, and 12-796, in comparison with their respective original populations and the susceptible check cultivar Rumba, indicating that through additional selection cycles, further progress is possible [59]. In Tanzania, entries 'VI038512' and 'AVON 1067' were identified as resistant, while entry 'VI038552' was identified as highly resistant [60]. In Brazilian semi-arid regions, 'Vale Ouro IPA 11', 'BRS Alfa São Francisco', 'Franciscana IPA 10' and 'Sirius F1' produced large average bulb yields while under thrips pressure, exhibiting simple negative correlations between bulb commercial yield and nymph degree of infestation [61]. In the Punjab region of India, 'NIKSP-86' was identified as highly thrips resistant and 'T-821' and 'Ceylon' were identified as resistant [62].

The differences in cultivars for thrips damage have been associated with amounts and types of epicuticular leaf wax $[58,63,64]$. Most normal onion cultivars have waxy leaves with abundant amounts of epicuticular wax that allow the thrips to adhere to the leaf surface and cause damage (Figure 2) [64]. Cultivars with glossy leaves accumulate small amounts of epicuticular wax and appear lighter green in color (Figure 2). These cultivars experience slower growth of thrips population and less damage from thrips feeding [58,64-68]. In resistant and moderately resistant entries, the wax crystals occurred as filaments, rods, platelets, tubes and complex dendritic structures, and were densely arranged when leaves were scanned under an electron microscope [60]. Moreover, the amount of hentriacontanone-16 wax may influence the total amount of leaf wax relative to other epicuticular waxes [64]. Genetic studies of glossy plants suggest that the lower wax phenotypes are conditioned by a single recessive locus $(g l)$ [69]. Moreover, the glossy phenotype from the 'White Persian' cultivar has been mapped to chromosome 8 where a single recessive locus $\left(g l^{w p}\right)$ controls this trait and interacts with a region of chromosome 1 to increase waxy progeny numbers [70]. Some cultivars, such as Colorado \#6 and many Sweet 
Spanish cultivars, accumulate an intermediate amount of wax and are known as 'semiglossy' (Figure 2) [64]. A non-destructive analysis of amounts and types of epicuticular wax based upon reflectance spectroscopy will be helpful in characterizing leaf wax phenotypes of different Allium germplasm [71]. Moreover, a significant negative relationship between total phenol content and thrips damage was observed by studying the biochemical basis of resistance [60].

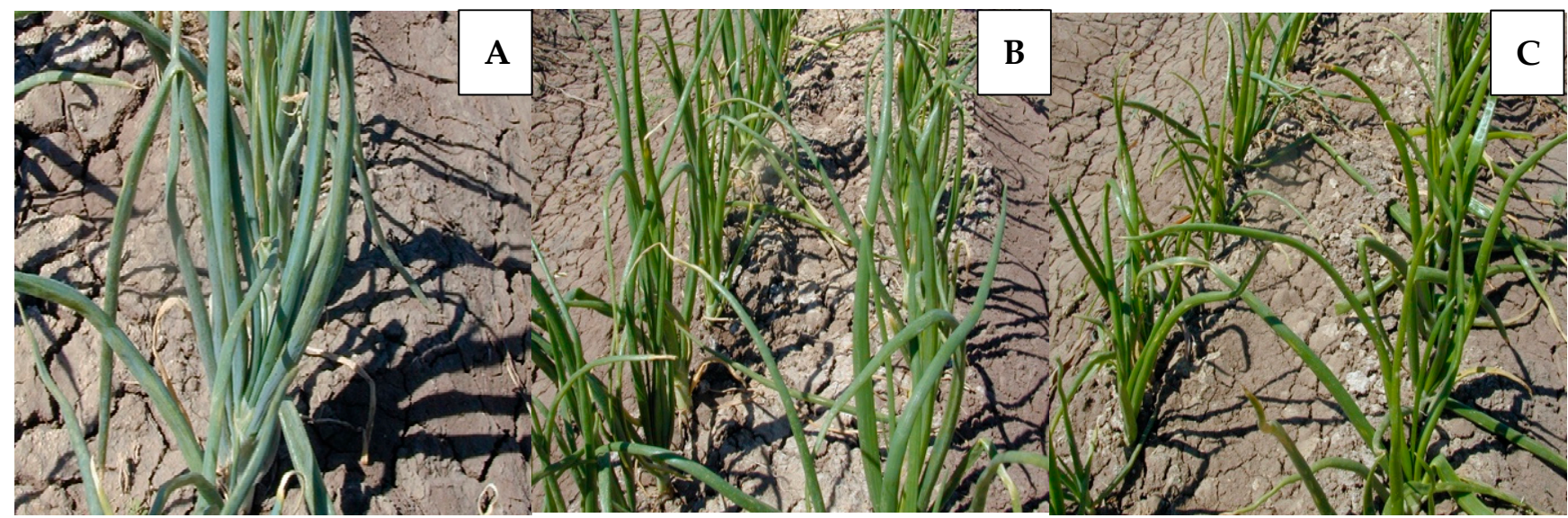

Figure 2. Onion leaves with varying amount of epicuticular wax, most (A) to least (C). Often leaf phenotypes are characterized as waxy (A), 'semi-glossy' (B), and glossy (C).

Leaf color also affects thrips feeding damage and thrips population, as it has been suggested that thrips prefer blue-colored foliage to light green and green-colored foliage [6,72-74]. Cultivars with a higher amount of epicuticular wax tend to have bluish leaves, and those with smaller amounts of wax tend to have greenish color [73,74]. 'Yankee' and 'Nebula' have bluish foliage and have exhibited higher thrips population [73,74], whereas 'Nebuka', which is a cultivar greenish in color, has displayed a significantly lower number of thrips when compared with 'Texas Early Grano 502', '951' and 'Creole' [63]. Moreover, plant architecture also seems to affect a cultivar's resistance to thrips since onion thrips mostly reside in the axil of the basal parts of the leaves. A significant negative correlation between leaf angle and thrips damage has been observed by clarification of the biophysical basis of resistance [60]. Moreover, negative correlations were observed between commercial bulb yield and central angle of the plant [61]. Therefore, cultivars with tighter leaf axils, such as 'White Persian', have been suggested to be more thrips resistant since they prevent access to the leaf axil [58].

Other organisms associated with onion may play a role in thrips feeding and IYSV replication. When onion seeds were inoculated with a fungal endophyte, Hypocrea lixii Pat., reduced thrips feeding was observed on the resulting plants as compared to plants derived from uninoculated seeds when plants from both groups were challenged with onion thrips [75-77]. Since there was less feeding by onion thrips on plants inoculated with a fungal endophyte, there was less IYSV transmission as compared to plants without an endophyte inoculation [77]. In addition, virus titer levels at 4 weeks after viral transmission were less in plants that had been inoculated with a fungal endophyte than plants had not been [77]. Since virus titer levels were similar after 1 week for both groups of plants, the inoculation with a fungal endophyte appeared to reduce virus replication within the plant [77]. These results suggest that an evaluation of the fungal endophytes that enter into a relationship with onion might be warranted and useful in the control of onion thrips and IYS. Onion genotypes could be evaluated for their fungal endophyte community and selected based on certain endophytes being present.

Since IYSV is transmitted by onion thrips, attempts have been made to separate both organisms through mechanical inoculation of onion plants using IYSV for screening purposes $[56,78]$. Mechanical inoculation of IYSV has proven ineffective in causing IYS on 
onions as the transmission rate is low $[77,78]$. Germplasm evaluation for IYS resistance has relied upon field evaluations [51,55,56,79-86]. One problem with field evaluations is ensuring that IYSV is present in the field and equally distributed throughout the field. Since mechanical inoculation is not effective in reliably producing IYS, disease development is dependent upon thrips transmission throughout the field. A "green bridge" between different plantings or life cycles of onions has been shown to result in viral transmission [6]. A field layout for evaluating of onion germplasm for IYS resistance has been developed that relies upon this "green bridge" effect [51,55,56,80-82]. Dormant onion bulbs from a previous onion crop are placed around the periphery of the evaluation field and inside the field if it is particularly large (Figure 3). These bulbs come from plants that previously expressed IYS symptoms when they were actively growing. IYSV has expressed a low ability to translocate throughout an onion plant $[6,78]$. For IYSV to be present in the newly expanded leaves of a bulb leaving dormancy, the virus must translocate from the infection points in the leaves from the previous year through the basal plate and into the inner fleshy scale leaves that exist during dormancy. Adult onion thrips have been shown to reside underneath the innermost dry scale layer and feed on the first fleshy scale layer while the bulb is dormant. If these thrips are viruliferous, they can infect onion leaves with IYSV once dormancy is broken. In the following year, planted bulbs will produce flower scapes and lose most of their vegetative leaves. For thrips to persist in the field, actively growing onion plants with abundant healthy green leaves must be present in the field. In an IYS evaluation field, the seed of a fall-sown, overwintering, IYS-susceptible, short day onion cultivar is sown on beds adjacent to beds that have planted bulbs. The beds that remain in between the beds with the direct-sown onion cultivar are used for evaluation. During the evaluation, onion thrips are not controlled in any fashion. This field layout ensures that thrips and IYSV are present in the field and that both thrips and IYSV are spread throughout the field such that every evaluated plant is challenged with thrips and IYSV and has the potential to develop IYS.

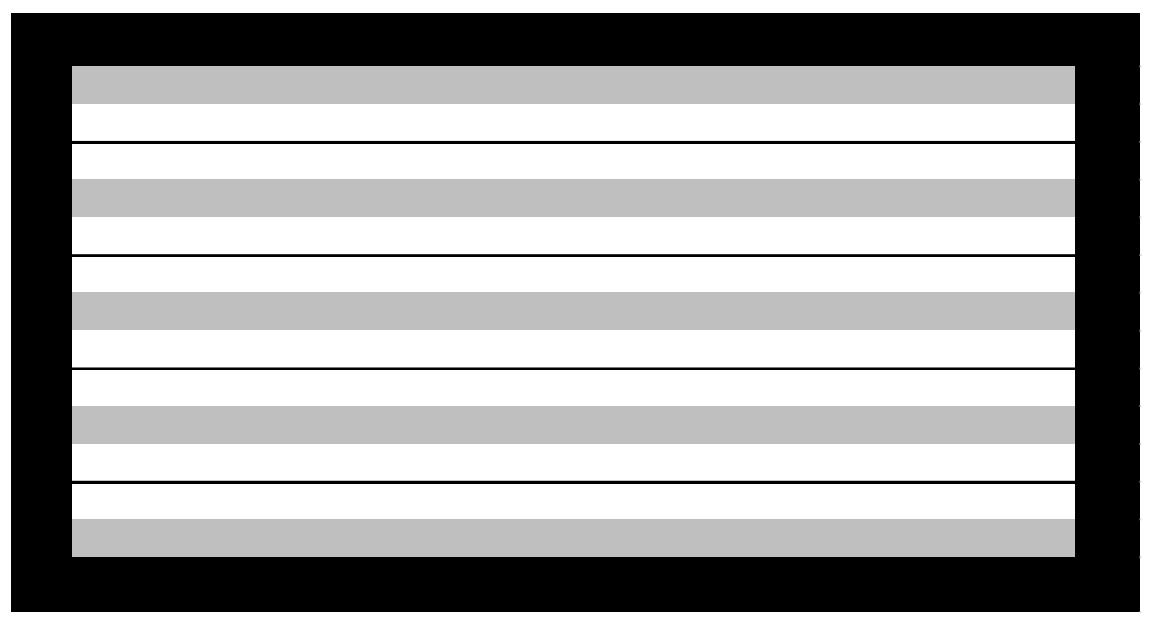

Figure 3. Field design utilized for evaluating onion germplasm for Iris yellow spot susceptibility. Black border represents border rows grown from viruliferous thrips-containing onion bulbs saved from previous year. Gray rows represent spreader rows. White rows represent test entries. Adapted from Singh and Cramer [38].

This field layout has been used to evaluate onion germplasm for susceptibility/resistance to IYS through disease symptom incidence and expression [53,57,58,82-84]. Among 11 winter-sown entries, the breeding line NMSU 05-33-1 showed fewer IYS symptoms than other entries [55]. In a similar evaluation, plants of NMSU 05-35-1 and 'Cometa' were more tolerant to IYS and had lower levels of IYSV than plants of other entries [84]. When 75 different plant introduction (PI) accessions were evaluated, plants of PIs 239633 and 546192 exhibited fewer IYS disease symptoms than plants of most accessions [53]. Other 
germplasm evaluations for IYS susceptibility have been conducted without a similar field layout [83-87].

The field layout mentioned has also been used to make individual plant selections for reduced symptom expression and to evaluate the progress achieved for reduced disease from these selections $[56,80,81,86]$. When selections were made from PI accessions, selected breeding lines, NMSU 10-575-1, 10-577-1, and 10-582-1, exhibited less IYS severity than their original accessions [56]. After one cycle of selection, plants of selected breeding lines, NMSU 10-776, 10-782, 10-785, 10-807, and 10-813, had less disease and less severe symptoms than plants of their respective previous generation [81]. When a second cycle of selection was conducted, further gains were accomplished to reduce IYS disease severity and incidence compared to the initial generations and a susceptible check [80]. Several of the same selected breeding lines were evaluated at a second location and exhibited less IYS damage than three commercial cultivars [86].

\section{Pungency}

Allium species are known for their distinctive flavor. In particular, onion flavor is characterized by not only its pungent taste but also by its aromatic lachrymatory qualities. This unique plant chemistry encompassing all aspects of onion flavor has been a pungent topic for over 60 years [88]. The onion flavor is a rich mixture of several compounds produced in the bulb, including organosulfur compounds, organic acids, and soluble solids or sugars [89-93]. Differences in these compounds are attributed to the amounts of precursors available for each compound; largely determined by the genetic background of each cultivar and the environment that they are grown in [92,94,95]. However, the most important compounds involved in lachrymatory effects and mouth pungency are the organosulfur compounds. Their synthesis is highly dependent on the destruction of onion tissue, which aids in releasing enzymes from the plant cell vacuole that produce pungent and lachrymatory compounds [88,93].

The sulfur in the onion organosulfur compounds originates from the uptake of sulfate $\left(\mathrm{SO}_{4}{ }^{2}\right)$ in the growing media and the subsequent incorporation of sulfur into cysteine $[74,92]$. From cysteine, a group of compounds, S-alk(en)yl cysteine sulfoxides, are synthesized including 1-propenyl-L-cysteine sulfoxide (PRENCSO), the precursor to the lachrymatory factor, and thiosulfinates that are associated with raw fresh onion and pungency sensations [93]. In order for PRENCSO to produce these compounds, destruction of the onion cells must occur to release two enzymes, alliinase and lachrymatory factor synthase [91]. Alliinase is only found in onions and converts PRENCSO into pyruvic acid, ammonia, and 1-propenylsulphenic acid [91,96]. The second enzyme involved in the organosulfur compound biosynthesis pathway is lachrymatory factor synthase, which converts 1-propenylsulphenic acid to propanthial S-oxide (the lachrymatory factor) and thiosulfinate [90]. The lachrymatory factor (LF) is known as the compound that causes tearing and gives heat and burning sensations.

Due to the many S-alk(en)yl cysteine sulfoxides in onions, there is great diversity in thiosulfinates with organoleptic flavor notes, including cabbage/onion, green onion/chive, raw fresh onion, pungent, heat and mouth burn [93]. Interestingly, Eady et al. detected novel compounds in the analysis of thiosulfinates in raw onion [97]. They found that during gas chromatography analysis of raw onion extracts, the instrument's column heat caused a reaction similar to that of cooking. From this reaction, disulfides and dihydrothiophenes were produced and detected by the analysis. These compounds are sweeter and are the aroma and flavor of cooked or fried onions. Moreover, thiosulfinates are known to have antiasthmatic activity and antiplatelet-aggregation activity [97].

The production of LF and thiosulfinates is dependent on onion genetics, sulfur amount in the soil, and storage conditions. Many studies have indicated that variation in onion flavor compounds is primarily determined by genetics [94]. Several studies have found that the amount of sulfur in the soil is directly associated with the amount of onion organosulfates like LF and thiosulfinates [91,98]. After growing 'Southport White Globe' 
onions in five sulfur treatments that ranged from low to high amounts of sulfur, Randle et al. found that many S-alk(en)yl cysteine sulfoxides and LF increased as sulfur amounts increased [98]. A separate study showed that while the increased sulfur amount increased LF and thiosulfinate amounts, it did not have an effect on sugar production [91].

Developing tearless onions with low pungency or low LF is a challenge due to the complex biosynthetic pathway and the difficulty in measuring the many compounds involved in flavor and pungency. To measure both organosulfates and volatile compounds in large populations of onions, breeders must extract and analyze the compounds with gas chromatography or high-performance liquid chromatography instruments. This process can quickly become very expensive and time consuming when studying large breeding populations. As a result, for decades, breeders have been measuring pyruvic acid, a byproduct of the alliinase reaction step $[88,96,99]$. Measuring pyruvic acid has made it extremely easy to measure pungency indirectly in thousands of onion plants [99].

In 2008, Eady et al. published research successfully silencing LF synthase, previously described as the enzyme synthesizing the LF [90,97]. Using RNA interference, the LF synthase enzyme was turned off in six plants leading to a significant reduction in the irritating LF compound that causes tears [97]. Interestingly, thiosulfinate production increased, as well as its downstream products, zwiebelane, both of which have medicinal properties in humans [97]. Another method of eliminated LF in onions was published by Kato et al. [100]. By self-pollinating plants from irradiated seeds with neon-ion, populations of tearless onions were produced. The long-day onion cultivar 'Super-Kitamomiji' was used for this study, and LF, pyruvic acid, and PRENCSO were measured in the third generation of the self-pollinated irradiated seeds. The radiation was successful in mutating the first enzyme in the PRENCSO to LF pathway, alliinase. Alliinase mRNA expression levels were low, and LF production was 7.5-fold lower than non-irradiated 'Super-Kitamomiji' [100]. Most recently, Yoo et al. were successful in breeding a short-day onion with reduced amounts of pyruvic acid by recurrent selection after three selections [91]. They reported a decrease in pyruvic acid by 1.0-1.5 mM compared to parental lines [91]. Low pungent onion have also been developed by recurrent selection in long-day onions resulting in the trade names 'Sunions' [101] and 'Evermild'.

The success that breeders and molecular geneticists have achieved in developing tearless onions is promising due to the previous work that biochemist and molecular biologists conducted in understanding the role of alliinase and lachrymatory factor synthase in the production of the tearful LF and flavorful thiosulfinates. Moving forward, to aid the future of developing more tearless onions, additional interdisciplinary research by biochemists and breeders will help in screening and selecting low pungency tearless onions.

\section{Bulb Dormancy and Vernalization}

For more than 70 years, long-day onion breeders have sought an annual cycle breeding scheme to improve the efficiency of the typical biennial cycle [102,103], but little work has taken place to precisely quantify the vernalization and dormancy thresholds that might make such a scheme possible. In a typical long-day breeding scheme, bulbs are either overwintered in cold storage or left in the field to flower in the season after bulb production [4]. During this period, both the vernalization and dormancy requirements must be satisfied. These two physiological processes overlap in long-day onion. Even though the total time from seed to seed is less than 24 months in a typical biennial breeding scheme, two growing seasons are generally required for this process.

D'Angelo and Goldman [104] determined that uniform scape emergence in a greenhouse can be achieved in many long day onion genotypes with vernalization times of 12-14 weeks at $10^{\circ} \mathrm{C}$. They also examined the dormancy requirement for long-day onion and found that most long-day germplasm has an endodormancy period of 8-10 weeks [105]. They discovered that breaking dormancy and initiating root growth can be facilitated by a four-hour treatment of bulbs with $15 \%$ hydrogen peroxide [104]. Using this information, they determined that bulbs could be treated within the first ten days postharvest 
with hydrogen peroxide to promote the breaking of dormancy and the initiation of root growth, and then subjected to precise vernalization times to reduce the time needed for the reproductive stage of growth.

For this breeding method to be effective, bulbs can be harvested from breeding plots and stored in a well-ventilated storage room for no longer than ten days before a four-hour treatment with a $30 \%$ solution of stabilized hydrogen peroxide $\left(\mathrm{H}_{2} \mathrm{O}_{2}\right)$ that is diluted 1:1 with purified water (Figure 4). The top one-third of the bulb is cut prior to placement in hydrogen peroxide. Bulbs are then placed in nursery pots and planted in a $20^{\circ} \mathrm{C}$ greenhouse under 16-h daylength to promote root formation, and then transferred after three weeks to a $10{ }^{\circ} \mathrm{C}$ temperature-controlled growth chamber with fluorescent lighting under $16 \mathrm{~h}$ of daylength with a photon flux density of $10.3 \mu \mathrm{mol} \mathrm{m} \mathrm{m}^{-2} \mathrm{~s}^{-1}$. After the appropriate vernalization period (from 12-14 weeks depending on genotype), bulbs can be transferred back to the $20^{\circ} \mathrm{C}$ greenhouse for flowering and seed production [3].

To prevent indirect selection for bolting susceptibility $[4,106]$, this method focuses on using the optimum vernalization time for each genotype, which is the minimum chilling time required for floral initiation. Optimum vernalization time and optimum storage time are different in that optimum vernalization time describes the chilling period following the release of endodormancy. As sprouted and un-sprouted bulbs vernalize at different rates, the dormancy status of a bulb can influence the time needed for vernalization [106-108]. This method will require additional fine-tuning before it can be adopted on a large scale. A short period of chilling may not be adequate for promoting flowering in some long-day onion germplasm; however, for many of the commercial germplasm sources investigated, shorter vernalization times coupled with dormancy breaking treatments can significantly shorten the time for onion breeders to move from seed to seed in their breeding nurseries [3]. Bulb annualization will likely not double the rate of genetic gain in long-day onion, but it may reduce the time from initial crossing to varietal release by several years. It is essential to mention that this system will likely not be adequate to evaluate traits associated with bulb storage quality, which will require a biennial breeding approach.
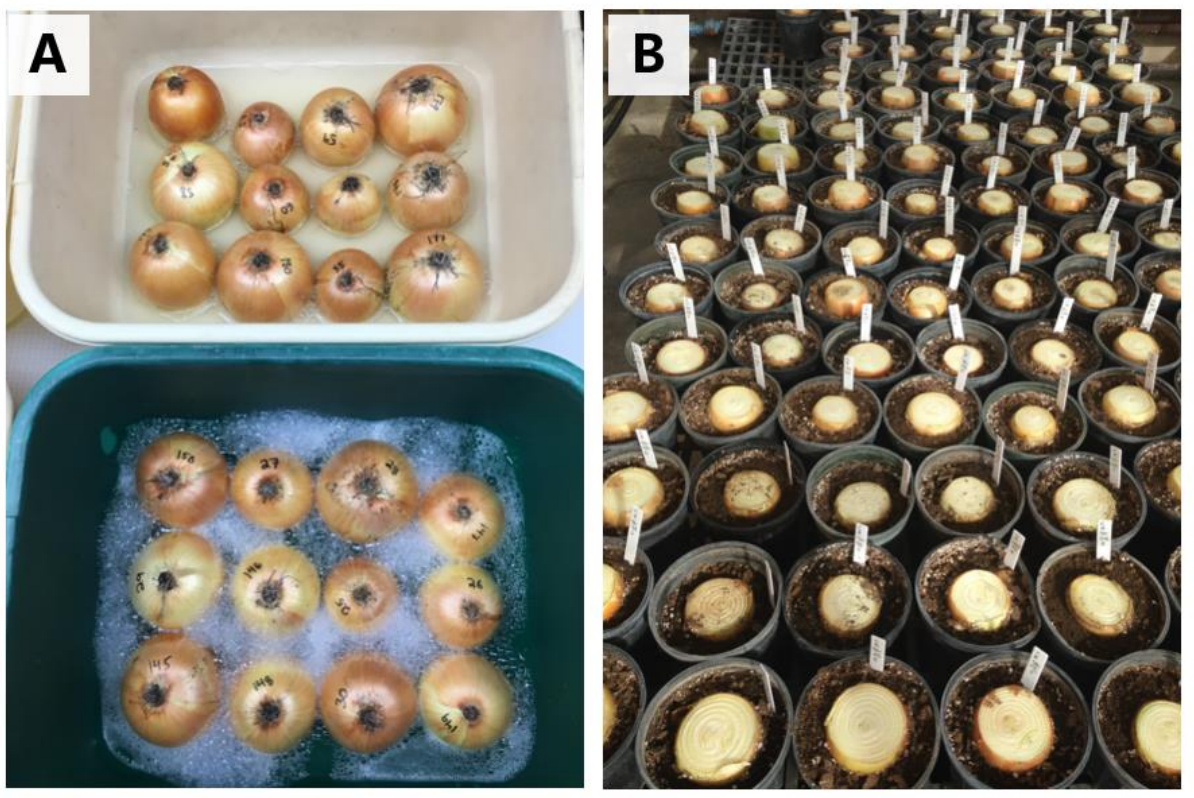

Figure 4. Cont. 

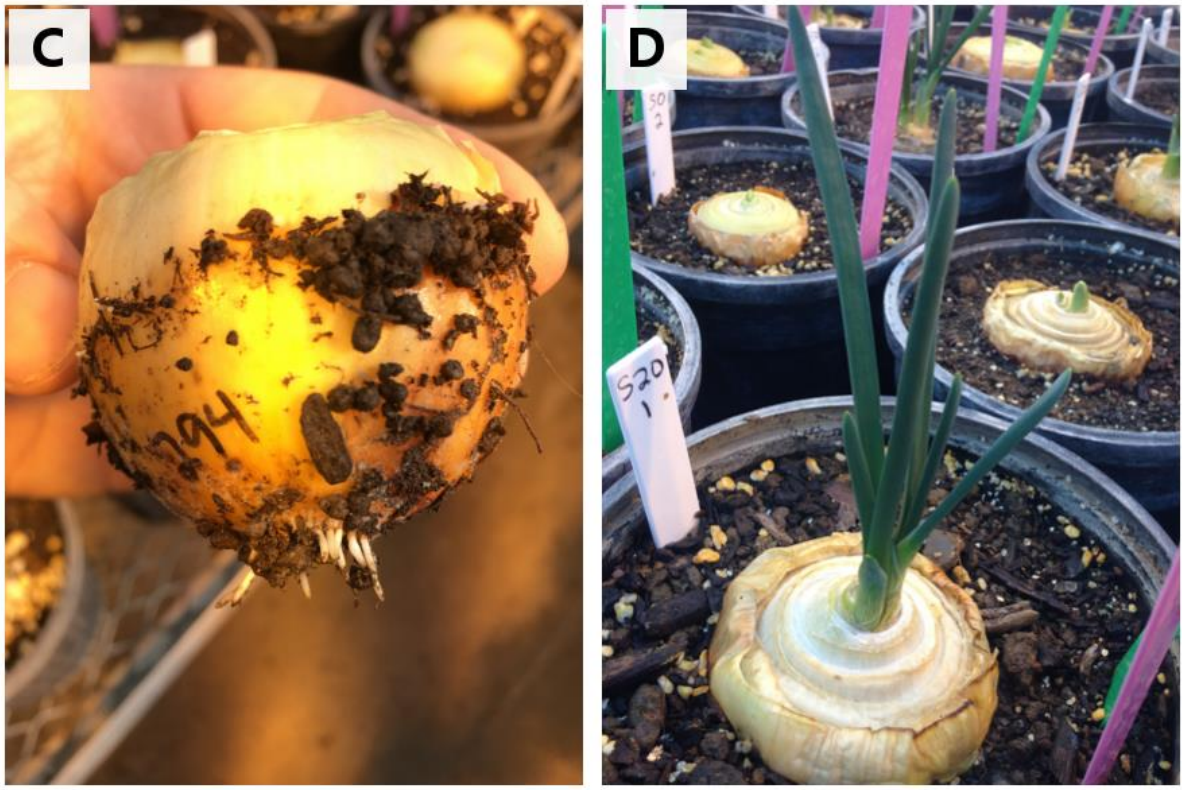

Figure 4. (A) Cut onion bulbs soaking in a 30\% hydrogen peroxide solution. The top bucket is filled with sodium stannate-stabilized hydrogen peroxide, the bottom bucket contains phosphate-stabilized hydrogen peroxide. Note the difference in foaming between the two solutions. (B) Onions planted in the greenhouse following treatment with hydrogen peroxide. (C) Rooting onion in the greenhouse. Bulbs were lifted from the soil to observe and record initial root growth. (D) Sprouting 'Sherman' onion from the $20 \%$ treatment group. Photos courtesy of C. D'Angelo. Reprinted with permission from The American Society for Horticultural Science [108].

\section{Conclusions}

Recent research has advanced our knowledge regarding onion breeding and genetics with much time spent on onion pests and diseases. For Fusarium basal rot, a reliable screening method involving the inoculation of mature bulbs has been developed and successfully used to select and develop onion germplasm that develops less severe disease symptoms when inoculated with the disease-causing pathogen. Onion germplasm has been evaluated for reduced thrips feeding preference and a leaf phenotype of less and differing compositions of epicuticular wax has been associated with lower onion thrips numbers. Lower thrips numbers have been associated with less Iris yellow spot disease symptoms. Breeding lines have been developed that exhibit less disease symptoms when challenged with onion thrips and IYSV. In addition to stress tolerance, breeding for improved quality traits has been the focus of recent research. The development of low pungency, tearless onions has been accomplished through conventional breeding and the genetic manipulation of genes associated with pungency and the lachrymatory factor. Every onion breeding program wants to reduce the biennial generation time to an annual cycle while still making selection progress. In long day onions, research on breaking bulb dormancy and ensuring proper vernalization has resulted in an annual generation time. Continued research in these and other emerging areas important to onion breeding and genetics in the future will advance onion genetic improvement for generations to come.

Author Contributions: Conceptualization, C.S.C.; resources, C.S.C., I.G. (Irwin Goldman), I.G. (Ivette Guzman), S.M., S.S.N., and S.S.; writing-original draft preparation, C.S.C., I.G. (Irwin Goldman), I.G. (Ivette Guzman), S.M., S.S.N., and S.S.; writing-review and editing, C.S.C., I.G. (Irwin Goldman), I.G. (Ivette Guzman), S.M., S.S.N., and S.S.; supervision, C.S.C.; project administration, C.S.C. All authors have read and agreed to the published version of the manuscript.

Funding: The authors thank the New Mexico Agricultural Experiment Station for the financial support of research mentioned in this review. 
Institutional Review Board Statement: Not applicable.

Informed Consent Statement: Not applicable.

Data Availability Statement: Data sharing not applicable.

Conflicts of Interest: The authors declare no conflict of interest.

\section{References}

1. FAOSTAT. Food and Agriculture Commodity Production Data; Food and Agriculture Organization: Rome, Italy, 2018.

2. Jones, H.A.; Mann, L.K. Onions and Their Allies; London Leonard Hill [Books] Limited Interscience Publishers, Inc.: New York, NY, USA, 1963; p. 284.

3. D'Angelo, C.J.; Goldman, I.L. Annualization of the long-day onion breeding cycle through threshold vernalization and dormancy disruption. Crop Breed. Genet. Genom. 2019, 1, e190009. [CrossRef]

4. Pike, L.M. Onion Breeding. In Breeding Vegetable Crops; AVI Publishing Co.: Westport, CT, USA, 1986; pp. $357-394$.

5. Schwartz, H.F.; Mohan, S.K. Compendium of Onion and Garlic Diseases; APS Press: St. Paul, MN, USA, 1985.

6. Gent, D.H.; du Toit, L.J.; Fichtner, S.F.; Mohan, S.K.; Pappu, H.R.; Schwartz, H.F. Iris yellow spot virus: An emerging threat to onion bulb and seed production. Plant Dis. 2006, 90, 1468-1480. [CrossRef] [PubMed]

7. Cramer, C.S. Breeding and genetics of Fusarium basal rot resistance in onion. Euphytica 2000, 115, 159-166. [CrossRef]

8. Selby, A.D. A brief handbook of the diseases of cultivated plants in Ohio. In Ohio Agricultural Experiment Station Bulletin Number 214; Ohio Agricultural Experiment Station: Columbus, OH, USA, 1910.

9. Saxena, A.; Cramer, C.S. Screening of onion seedlings for resistance against New Mexico isolates of Fusarium oxysporum f.sp. cepae. J. Plant Pathol. 2009, 91, 197-200.

10. Rabiei-Motlagh, E.; Falahati-Rastegar, M.; Rouhani, H.; Jafarpour, B.; Jahanbakhsh, V. Root diseases of onion caused by some root colonizing fungi in northeast of Iran. Am. J. Agric. Environ. Sci. 2010, 7, 484-491.

11. Southwood, M.J.; Viljoen, A.; Mostert, L.; Rose, L.J.; McLeod, A. Phylogenetic and biological characterization of Fusarium oxysporum isolates associated with onion in South Africa. Plant Dis. 2012, 96, 1251-1261. [CrossRef] [PubMed]

12. Taylor, A.; Vagany, V.; Barbara, D.J.; Thomas, B.; Pink, D.A.C.; Jones, J.E.; Clarkson, J.P. Identification of differential resistance to six Fusarium oxysporum f.sp. cepae isolates in commercial onion cultivars through the development of a rapid seedling assay. Plant Pathol. 2013, 62, 103-111. [CrossRef]

13. Esfahani, M.N. Genetic and virulence variation in Fusarium oxysporum f.sp. cepae causing root and basal rot of common onion in Iran. J. Phytopathol. 2018, 166, 572-580. [CrossRef]

14. Vivero, G.A.G. Resistance to Fusarium Basal Rot and Response to Arbuscular Mycorrhizal Fungi in Allium. Ph.D. Dissertation, Wageningen University, Wageningen, The Netherlands, 2009.

15. Kalman, B.; Abraham, D.; Graph, S.; Perl-Treves, R.; Harel, Y.M.; Degani, O. Isolation and identification of Fusarium spp., the causal agents of onion (Allium cepa) basal rot in Northeastern Israel. Biology 2020, 9, 69. [CrossRef] [PubMed]

16. Havey, M.J. Onion and other cultivated Alliums. In Evolution of Crop Plants; Smart, J., Simmonds, N.W., Eds.; Wiley: New York, NY, USA, 1995; pp. 344-350.

17. Bennett, A.J.; Bending, G.D.; Chandler, D.; Hilton, S.; Mills, P. Meeting the demand for crop production: The challenge of yield decline in crops grown in short rotations. Biol. Rev. 2012, 87, 52-71. [CrossRef] [PubMed]

18. Thornton, M.K.; Mohan, S.K. Response of sweet spanish onion cultivars to basal rot and pink root. Plant Dis. 1996, 80, 660-663. [CrossRef]

19. Taylor, A.; Teakle, G.R.; Walley, P.G.; Finch-Savage, W.E.; Jackson, A.C.; Jones, J.E.; Hand, P.; Thomas, B.; Havey, M.J.; Pink, D.A.; et al. Assembly and characterisation of a unique onion diversity set identifies resistance to Fusarium basal rot and improved seedling vigour. Theor. Appl. Genet. 2019, 132, 3245-3264. [CrossRef] [PubMed]

20. Caligiore-Gei, P.F.; Valdez, J.G.; Piccolo, R.J.; Galmarini, C.R. Influence of Fusarium spp. isolate and inoculum density on resistance screening tests in onion. Trop. Plant Pathol. 2014, 39, 19-27. [CrossRef]

21. Mandal, S.; Cramer, C.S. An artificial inoculation method to select mature onion bulbs resistant to fusarium basal rot. HortScience 2020, 55, 1840-1847. [CrossRef]

22. Taylor, A.; Vágány, V.; Jackson, A.C.; Harrison, R.J.; Rainoni, A.; Clarkson, J.P. Identification of pathogenicity-related genes in Fusarium oxysporum f. sp. cepae. Mol. Plant Pathol. 2016, 17, 1032-1047. [CrossRef] [PubMed]

23. Armitage, A.D.; Taylor, A.; Sobczyk, M.K.; Baxter, L.; Greenfield, B.P.J.; Bates, H.J.; Fiona, W.; Jackson, A.C.; Ott, S.; Harrison, R.J.; et al. Characterisation of pathogen-specific regions and novel effector candidates in Fusarium oxysporumf. sp. cepae. Sci. Rep. 2018, 8, 1-15. [CrossRef] [PubMed]

24. Mahdy, H. Identification of Fusarium Species Causing Onion Basal Rot in Egypt and Their Virulence on seeds, Seedlings and Onion Bulbs. Ann. Agric. Sci. Moshtohor 2018, 56, 79-88. [CrossRef]

25. Armitage, A.D.; Taylor, A.; Hulin, M.T.; Jackson, A.C.; Harrison, R.J.; Clarkson, J.P. Draft Genome Sequence of an Onion Basal Rot Isolate of Fusarium proliferatum. Microbiol. Resour. Announc. 2019, 8, 6-8. [CrossRef] [PubMed]

26. Bektast, I.; Kusek, M. Phylogenetic and Morphological Characterization of Fusarium Oxysporum f. sp. cepae the Causal Agent of Basal Rot on Onion Isolated From Turkey. Fresenius. Environ. Bull. 2019, 28, 1733-1742. 
27. Latvala, S.; Haapalainen, M.; Kivijärvi, P.; Suojala-Ahlfors, T.; Iivonen, S.; Hannukkala, A. Sampling and PCR method for detecting pathogenic Fusarium oxysporum strains in onion harvest. Lett. Appl. Microbiol. 2020, 70, 210-220. [CrossRef]

28. Mandal, S.; Saxena, A.; Cramer, C.S.; Steiner, R.L. Comparing efficiencies of two selection approaches for improving Fusarium basal rot resistance in short-day onion after a single cycle of selection. Horticulturae 2020, 6, 26. [CrossRef]

29. Esfahani, M.N.; Hosseini, M.; Nasehi, A.; Golkhandan, E. Screening of onion seed sets for resistance against new iranian isolates of Fusarium oxysporum f.sp. cepa. Arch. Phytopath. Plant Prot. 2013, 46, 1864-1873. [CrossRef]

30. Rout, E.; Tripathy, P.; Nanda, S.; Nayak, S.; Joshi, R.K. Evaluation of cultivated and wild Allium accessions for resistance to Fusarium oxysporum f.sp. cepae. Proc. Natl. Acad. Sci. India. Sect. B Biol. Sci. 2016, 86, 643-649. [CrossRef]

31. Caligiore-Gei, P.F.; Ciotti, M.L.; Valdez, J.G.; Galmarini, C.R. Breeding onion for resistance to Fusarium basal rot: Comparison of field selection and artificial inoculation. Trop. Plant Pathol. 2020, 45, 493-498. [CrossRef]

32. Saxena, A. Screening of Onion Cultivars for Fusarium Basal Rot and Spatial Distribution of Fusarium oxysporum f.sp. cepae. Master's Thesis, New Mexico State University, Las Cruces, NM, USA, 2007.

33. Busby, P.E.; Ridout, M.; Newcombe, G. Fungal endophytes: Modifiers of plant disease. Plant Mol. Biol. 2016, 90, 645-655. [CrossRef] [PubMed]

34. Abawi, G.S.; Lorbeer, J.W. Populations of Fusarium oxysporum f.sp. cepae in organic soils in New York. Phytopathology 1971, 61, 1042-1048. [CrossRef]

35. Mandal, S.; Cramer, C.S. Breeding for fusarium basal rot resistance in short-day onions. HortScience 2018, 53, S287.

36. Mandal, S.; Cramer, C.S. Advancement in breeding for Fusarium basal rot resistance of onion (Allium cepa L.). HortScience 2020, $55, \mathrm{~S} 22$.

37. Mandal, S.; Cramer, C.S. Can onion tolerate a storage rot? In Proceedings of the American Society of Agronomy, the Crop Science Society of America, and the Soil Science Society of America International Annual Meeting, Madison, WI, USA, 9-13 November 2020.

38. Marzu, J.C. Genetic Analyses of Resistances to Fusarium Basal Rot and Pink Root in Onion. Master's Thesis, University of Wisconsin-Madison, Madison, WI, USA, 2015.

39. Teshima, Y.; Ikeda, T.; Imada, K.; Sasaki, K.; El-Sayed, M.A.; Shigyo, M.; Tanaka, S.; Ito, S. Identification and biological activity of antifungal saponins from shallot (Allium cepa L. Aggregatum Group). J. Agric. Food Chem. 2013, 61, 7440-7445. [CrossRef]

40. Vu, H.Q.; El-Sayed, M.A.; Ito, S.I.; Yamauchi, N.; Shigyo, M. Discovery of a new source of resistance to Fusarium oxysporum, cause of Fusarium wilt in Allium fistulosum, located on chromosome 2 of Allium cepa Aggregatum group. Genome 2012, 55, 797-807. [CrossRef]

41. Abdelrahman, M.; El-Sayed, M.; Sato, S.; Hirakawa, H.; Ito, S.; Tanaka, K.; Mine, Y.; Sugiyama, N.; Suzuki, M.; Yamauchi, N.; et al. RNA-sequencing-based transcriptome and biochemical analyses of steroidal saponin pathway in a complete set of Allium fistulosum-A cepa monosomic addition lines. PLoS ONE 2017, 12, e0181784. [CrossRef]

42. Lewis, T. Pest thrips in perspective. In Thrips as Crop Pests; Lewis, T., Ed.; CAB International: New York, NY, USA, 1997 ; pp. 1-13.

43. Cranshaw, W.S. Thrips. In Compendium of Onion and Garlic Diseases and Pests, 2nd ed.; Schwartz, H.F., Mohan, S.K., Eds.; APS Press: Minneapolis, MN, USA, 2008; pp. 89-91.

44. Diaz-Montano, J.; Fuchs, M.; Nault, B.A.; Fail, J.; Shelton, A.M. Onion thrips (Thysanoptera: Thripidae): A global pest of increasing concern in onion. J. Econ. Entomol. 2011, 104, 1-13. [CrossRef] [PubMed]

45. Fournier, F.; Boivin, G.; Stewart, R. Effect of Thrips tabaci (Thysanoptera: Thripidae) on yellow onion yields and economic thresholds for its management. J. Econ. Entomol. 1995, 88, 1401-1407. [CrossRef]

46. Leach, A.; Fuchs, M.; Harding, R.; Nault, B.A. Iris Yellow Spot Virus Prolongs the Adult Lifespan of Its Primary Vector, Onion Thrips (Thrips tabaci) (Thysanoptera: Thripidae). J. Insect Sci. 2019, 19, 3. [CrossRef] [PubMed]

47. Kritzman, A.; Lampel, M.; Raccah, B.; Gera, A. Distribution and transmission of Iris yellow spot virus. Plant Dis. 2001, 85, 838-842. [CrossRef] [PubMed]

48. Nagata, T.; Almeida, A.C.L.; Resende, R.D.O.; de Ávila, A.C. The identification of the vector species of iris yellow spot tospovirus occurring on onion in Brazil. Plant Dis. 1999, 83, 399. [CrossRef] [PubMed]

49. Abdelkhalek, A.; ElMorsi, A.; AlShehaby, O.; Sanan-Mishra, N.; Hafez, E. Identification of genes differentially expressed in Iris yellow spot virus infected onion. Phytopathol. Mediterr. 2018, 257, 334-340.

50. Abdelkhalek, A.; Quari, S.H.; Hafez, E. Iris yellow spot virus -induced chloroplast malformation results in male sterility. J. Biosci. 2019, 44, 142. [CrossRef]

51. Cramer, C.S.; Singh, N.; Kamal, N.; Pappu, H.R. Screening onion plant introduction accessions for tolerance to onion thrips and Iris yellow spot. HortScience 2014, 49, 1253-1261. [CrossRef]

52. Shelton, A.M.; Nault, B.A.; Plate, J.; Zhao, J.Z. Regional and temporal variation in susceptibility to lambda-cyhalothrin in onion thrips, Thrips tabaci (Thysanoptera: Thripidae), in onion fields in NY. J. Econ. Entomol. 2003, 96, 1843-1848. [CrossRef] [PubMed]

53. Shelton, A.M.; Zhao, J.Z.; Nault, B.A.; Plate, J.; Musser, F.R.; Larentzaki, E. Patterns of insecticide resistance in onion thrips (Thysanoptera: Thripidae) in onion fields in NY. J. Econ Entomol. 2006, 99, 1798-1804. [CrossRef] [PubMed]

54. Allen, J.K.M.; Scott-Dupree, C.D.; Tolman, J.H.; Harris, C.R. Resistance of Thrips tabaci to pyrethroid and organophosphate insecticides in Ontario. Can. Pest Manag. Sci. 2005, 61, 809-815. [CrossRef] [PubMed]

55. Mohseni-Moghadam, M.M.; Cramer, C.S.; Steiner, R.L.; Creamer, R. Evaluating winter-sown onion entries for Iris yellow spot virus susceptibility. HortScience 2011, 46, 1224-1229. [CrossRef]

56. Singh, N.; Cramer, C.S. Improved tolerance for onion thrips and Iris yellow spot in onion plant introductions after two selection cycles. Horticulturae 2019, 5, 18. [CrossRef] 
57. Boateng, C.O.; Schwartz, H.F.; Havey, M.J.; Otto, K. Evaluation of onion germplasm for resistance to Iris yellow spot (Iris yellow spot virus) and onion thrips, Thrips tabaci. Southwest. Entomol. 2014, 39, 237-260. [CrossRef]

58. Jones, H.A.; Bailey, S.F.; Emsweller, S.L. Thrips resistance in onion. Hilgardia 1934, 8, 215-252. [CrossRef]

59. Kamal, N.; Shahabeddin Nourbakhsh, S.; Cramer, C.S. Reduced Iris Yellow Spot Symptoms through Selection within Onion Breeding Lines. Horticulturae 2021, 7, 12. [CrossRef]

60. Njau, G.M.; Nyomora, A.M.S.; Dinssa, F.F. Evaluation of onion (Allium cepa) germplasm entries for resistance to onion thrips, Thrips tabaci (Lindeman) in Tanzania. Int. J. Trop. Insect Sci. 2017, 37, 98-113. [CrossRef]

61. De Oliveira, F.G.; Santos, C.A.F.; Oliveira, V.R.; de Alencar, J.A.; da Silva, D.O.M. Evaluation of onion accessions for resistance to thrips in Brazilian semi-arid regions. J. Hortic. Sci. Biotechnol. 2017, 92, 550-558. [CrossRef]

62. Raut, A.M.; Pal, S.; Wahengbam, J.; Najitha Banu, A. Population dynamics of onion thrips (Thrips tabaci Lind., Thysanoptera; Thripidae) and varietal response of onion cultivars against onion thrips. J. Entomol. Res. 2020, 44, 547-554. [CrossRef]

63. Coudriet, D.L.; Kishaba, A.N.; McCreight, J.D.; Bohn, W.G. Varietal resistance in onions to thrips (Thysanoptera, Thripidae). J. Econ. Entomol. 1979, 72, 614-615. [CrossRef]

64. Damon, S.J.; Groves, R.L.; Havey, M.J. Variation for epicuticular waxes on onion foliage and impacts on numbers of onion thrips. J. Am. Soc. Hortic. Sci. 2014, 139, 495-501. [CrossRef]

65. Alimousavi, S.A.; Hassandokht, M.R.; Moharramipour, S. Evaluation of Iranian onion germplasms for resistance to thrips. Int. J. Agric. Biol. 2007, 9, 897-900.

66. Molenaar, N. Genetics, Thrips (Thrips tabaci L.) Resistance and Epicuticular Wax Characteristics of Nonglossy and Glossy Onions (Allium cepa L.). Ph.D. Thesis, University of Wisconsin, Madison, WI, USA, 1984.

67. Mote, U.N.; Sonone, H.N. Relative susceptibility of different varieties of onion (Allium cepa) to thrips (Thrips tabaci Lind.). J. Maharashtra Agric. Univ. 1977, 2, 152-155.

68. Pawar, B.B.; Patil, A.V.; Sonone, H.N. A thrips resistant glossy selection in white onions. Res. J. Mahatma Phule Agric. Univ. 1975, $6,152-153$.

69. Jones, H.A.; Clarke, A.E.; Stevenson, F.J. Studies in the genetics of the onion (Allium cepa L.). Proc. Am. Soc. Hort. Sci. 1944, $44,479-484$.

70. Munaiz, E.D.; Havey, M.J. Genetic analyses of epicuticular waxes associated with the glossy phenotype of 'White Persian' onion. J. Am. Soc. Hort. Sci. 2020, 145, 67-72. [CrossRef]

71. Munaiz, E.D.; Townsend, P.A.; Havey, M.J. Reflectance spectroscopy for non-destructive measurement and genetic analysis of amounts and types of epicuticular waxes on onion leaves. Molecules 2020, 25, 3454. [CrossRef] [PubMed]

72. Czencz, K. The role of coloured traps in collecting thrips fauna. In Population Structure, Genetics and Taxonomy of Aphids and Thysanoptera; Holman, J., Pelikan, J., Dixon, A.F.G., Weisman, L., Eds.; SPB Academic Publishing: The Hague, The Netherlands, 1987; pp. 426-435.

73. Kirk, W.D.J. Ecologically selective coloured traps. Ecol. Entomol. 1984, 9, 35-41. [CrossRef]

74. Diaz-Montano, J.; Fail, J.; Deutschlander, M.; Nault, B.A.; Shelton, A.M. Characterization of resistance, evaluation of the attractiveness of plant odors, and effect of leaf color on different onion cultivars to onion thrips (Thysanoptera: Thripidae). J. Econ. Entomol. 2012, 105, 632-641. [CrossRef] [PubMed]

75. Muvea, A.M.; Meyhöfer, R.; Maniania, N.K.; Poehling, H.-M.; Ekesi, S.; Subramanian, S. Behavioral responses of Thrips tabaci Lindemann to endophyte inoculated onion plants. J. Pest Sci. 2015, 88, 555-562. [CrossRef]

76. Muvea, A.M.; Meyhöfer, R.; Subramanian, S.; Poehling, H.-M.; Ekesi, S.; Maniania, N.K. Colonization of onions by endophytic fungi and their impacts on the biology of Thrips tabaci. PLoS ONE 2014, 9, e108242. [CrossRef]

77. Muvea, A.M.; Subramanian, S.; Maniania, N.K.; Poehling, H.-M.; Ekesi, S.; Meyhöfer, R. Endophytic colonization of onions induces resistance to viruliferous thrips and virus replication. Front. Plant Sci. 2018, 9, 1785. [CrossRef]

78. Bag, S.; Schwartz, H.F.; Cramer, C.S.; Havey, M.J.; Pappu, H.R. Iris yellow spot virus (Tospovirus: Bunyaviridae): From obscurity to priority. Mol. Plant Pathol. 2015, 16, 224-237. [CrossRef] [PubMed]

79. Multani, P.S.; Cramer, C.S.; Steiner, R.L.; Creamer, R. Screening winter-sown onion entries for Iris yellow spot virus tolerance. HortScience 2009, 44, 627-632. [CrossRef]

80. Kamal, N. Selection Progress and Cost Benefit Analysis of Iris Yellow Spot Resistance in Onions. Ph.D. Thesis, New Mexico State University, Las Cruces, NM, USA, 2016.

81. Kamal, N.; Cramer, C.S. Screening progress for resistance to Iris yellow spot in onions. HortScience 2018, 53, 1088-1094. [CrossRef]

82. Cramer, C.S.; Mohseni-Moghadam, M.; Creamer, R.J.; Steiner, R.L. Screening winter-sown entries for Iris yellow spot disease susceptibility. In Proceedings of the 2012 National Allium Research Conference, Las Cruces, NM, USA, 12-14 December 2012; Walker, S., Cramer, C.S., Eds.; New Mexico State University: Las Cruces, NM, USA, 2012; pp. 80-99.

83. Diaz-Montano, J.; Fuchs, M.; Nault, B.A.; Shelton, A.M. Evaluation of onion cultivars for resistance to onion thrips (Thysanoptera: Thripidae) and Iris yellow spot virus. J. Econ. Entomol. 2010, 103, 925-937. [CrossRef] [PubMed]

84. Du Toit, L.J.; Pelter, G.Q.; Pappu, H.R. IYSV challenges to the onion seed industry in Washington. In Proceedings of the National Allium Research Conference, Grand Junction, CO, USA, 8-10 December 2004; Swift, C., Ed.; Colorado State University: Ft. Collins, CO, USA, 2004; pp. 213-217. 
85. Reitz, S.R.; Cramer, C.S.; Shock, C.C.; Feibert, E.B.G.; Rivera, A.; Saunders, L.D. Evaluation of New Onion Lines for Resistance to Onion Thrips and Iris Yellow Spot Virus-Malheur Experiment Station Annual Report 2015; Oregon State University Agricultural Experiment Station Ext/CrS 156; Oregon State University: Corvallis, OR, USA, 2016; pp. 170-174.

86. Schwartz, H.F.; Gent, D.H.; Fichtner, S.F.; Hammon, R.W.; Khosla, R. Integrated management of Iris yellow spot virus in onion. In Proceedings of the 2004 National Allium Research Conference, Grand Junction, CO, USA, 8-10 December 2004; Swift, C., Ed.; Colorado State University: Ft. Collins, CO, USA, 2004; pp. 207-212.

87. Creamer, R.; Sanogo, S.; Moya, A.; Romero, J.; Molina-Bravo, R.; Cramer, C.S. Iris yellow spot virus on onion in New Mexico. Plant Dis. 2004, 88, 1049. [CrossRef] [PubMed]

88. Schwimmer, S.; Carson, J.F.; Makower, R.U.; Mazelis, M.; Wong, F.F. Demonstration of alliinase in a protein preparation from onion. Experientia 1960, 16, 449-450. [CrossRef]

89. Brodnitz, M.H.; Pascale, J.V. Thiopropanal s-oxide: A lachrymatory factor in onions. J. Agric. Food Chem. 1971, 19, 269-272. [CrossRef] [PubMed]

90. Imai, S.; Tsuge, N.; Tomotake, M.; Nagatome, Y.; Sawada, H.; Nagata, T.; Kumagai, H. An onion enzyme that makes the eyes water. Nature 2002, 419, 685. [CrossRef] [PubMed]

91. Randle, W.M.; Bussard, M.L. Pungency and sugars of short-day onions as affected by sulfur nutrition. J. Am. Soc. Hortic. Sci. 1993, 118, 766-770. [CrossRef]

92. Randle, W.M.; Lancaster, J.E.; Shaw, M.L.; Sutton, K.H.; Hay, R.L.; Bussard, M.L. Quantifying onion flavor compounds responding to sulfur fertility-sulfur increases levels of alk(en)yl cysteine sulfoxides and biosynthetic intermediates. J. Am. Soc. Hortic. Sci. 1995, 120, 1075-1081. [CrossRef]

93. Randle, W.M. Onion flavor chemistry and factors influencing flavor intensity. In Spices: Flavor Chemistry and Antioxidant Properties; Risch, S.J., Ho, C.T., Eds.; American Chemical Society: Washington, DC, USA, 1997; Volume 119, pp. 41-52. [CrossRef]

94. Kopsell, D.E.; Randle, W.M.; Eiteman, M.A. Changes in the s-alk(en)yl cysteine sulfoxides and their biosynthetic intermediates during onion storage. J. Am. Soc. Hortic. Sci. 1999, 124, 177-183. [CrossRef]

95. Yoo, K.S.; Pike, L.M.; Patil, B.S.; Lee, E.J. Developing sweet onions by recurrent selection in a short-day onion breeding program. Sci. Hortic. 2020, 266, 109269. [CrossRef]

96. Schwimmer, S.; Weston, W.J. Onion flavor and odor, enzymatic development of pyruvic acid in onion as a measure of pungency. J. Agric. Food Chem. 1961, 9, 301-304. [CrossRef]

97. Eady, C.C.; Kamoi, T.; Kato, M.; Porter, N.G.; Davis, S.; Shaw, M.K.; Kamoi, A.; Imai, S. Silencing onion lachrymatory factor synthase causes a significant change in the sulfur secondary metabolite profile. Plant Physiol. 2008, 147, 2096-2106. [CrossRef] [PubMed]

98. Randle, W.M.; Block, E.; Littlejohn, M.H.; Putnman, D.; Bussard, M.L. Onion (Allium cepa L.) thiosulfinates respond to increasing sulfur fertility. J. Agric. Food Chem. 1994, 42, 2085-2088. [CrossRef]

99. Yoo, K.S.; Pike, L.M.; Hamilton, B.K. A simplified pyruvic acid analysis suitable for onion breeding programs. HortScience 1995, 30, 1306. [CrossRef]

100. Kato, M.; Masamura, N.; Shono, J.; Okamoto, D.; Abe, T.; Imai, S. Production and characterization of tearless and non-pungent onion. Sci. Rep. 2016, 6, 23779. [CrossRef] [PubMed]

101. Vegetable Growers News: Sunion, the ‘Tearless' Onions, Hit Select Store Shelves. Available online: https: / / vegetablegrowersnews $\mathrm{com} /$ news/sunions-tearless-onions-hit-select-store-shelves / (accessed on 18 November 2020).

102. Scully, N.J.; Parker, M.W.; Borthwick, H.A. Interaction of nitrogen nutrition and photoperiod as expressed in bulbing and flower-stalk development of onion. Bot. Gaz. 1945, 107, 52-61. [CrossRef]

103. Van Kampen, I.J. Shortening the breeding cycle in onions (Allium cepa L.). Meded. Proefstn. Voor Groentet. Vollegrond Ned. 1970, $51,1-65$.

104. D'Angelo, C.J.; Goldman, I.L. Breaking onion bulb endodormancy with hydrogen peroxide. Accepted upon acceptable revision. HortScience 2019, 54, 1694-1702. [CrossRef]

105. D'Angelo, C.J.; Goldman, I.L. Temporal aspects of vernalization and flowering in long-day storage onion. J. Am. Soc. Hortic. Sci. 2018, 143, 446-453. [CrossRef]

106. Baldwin, S.; Revanna, R.; Pither-Joyce, M.; Shaw, M.; Wright, K.; Thomson, S.; Moya, L.; Lee, R.; Macknight, R.C.; McCallum, J.A. Genetic analyses of bolting in bulb onion (Allium cepa L.). Theor. Appl. Genet. 2014, 127, 535-547. [CrossRef] [PubMed]

107. Bertaud, D.S. Effects of chilling duration, photoperiod and temperature on floral initiation and development in sprouted and unsprouted onion bulbs. In Proceedings of the 4th EUCARPIA Allium Symposium, Wellesbourne, UK, 6-9 September 1988; pp. 254-261.

108. Shishido, Y.; Saito, T. Studies on the flower bud formation in onion plants III. Effects of physiologial conditions on the low temperature induction of flower buds in bulbs. J. Jpn. Soc. Hortic. Sci. 1977, 46, 310-316. [CrossRef] 